\title{
A03 ハマダラカ唾液腺におけるキサンツレン酸含量の定量分析
}

○新井明治, Okech Bernard A., 松岡裕之（自治医科大学 感染・免疫学講座 医動物学部門）

Quantitative analysis of xanthurenic acid in the salivary glands of Anopheles stephensi

Arai, M., Okech, B. A., Matsuoka, H.

マラリア原虫の生殖体形成は, ヒトからハマダラカへの伝播の最初の段階であり,トリプトファンの代謝産物であ るキサンツレン酸 (XA) によって誘導される. 我々はこれまでに, 1) ハマダラカは吸血の際に睡液を中腸内へ飲み下 すこと，2）ハマダラカの唾液腺に XA が含まれることを報告している. 今回我々は HPLC-ECD 分析により Anopheles stephensi の組織に含まれる微量のXA を定量する手法を確立し, 吸血前後で崜液腺のXA 含量がどのよ うに変化するかを調べた. 同一バッチのメス成虫をマウス吸血群と末吸血群に分けて唾液腺のXA 含量を測定した結 果, 未吸血蚊之吸血蚊のXA 含量はそれぞれ 1 匹あたり $284 \pm 46 \mathrm{pg}$ と $128 \pm 66 \mathrm{pg}$ であり, 吸血による喠液腺XA の有 意な減少が認められた。この結果は唾液腺の XA が吸血の際に中腸へ流入することで, 生殖体形成誘導に寄与する可 能性を示唆するものである.

\section{A04 トリプトファン添加によるハマダラカのキサンツレン酸含有量の変化}

○松岡裕之, オケッチバーナード, 新井明治 (自治医科大学医動物学部門)

Changes of xanthurenic acid contents in Anopheles stephensi by adding tryptophan

Matsuoka, H., Okech, B., Arai, M.

ハマダラカ唾液腺におけるキサンツレン酸 (XA)の測定は, 従来 Bioassay で行なっていたが, 今般 HPLC-ECDに より定量的に実施できるようになった. XAの産生はトリプトファン（Trp）を材料とするため, Trp の供給が断たれ れば八マダラカはXA をつくることができず, マラリアの伝播もできなくなるはずである. 今回我々は逆に, Trp ハマダラカに過剩に与えて, ハマダラカにおけるXA の変動, マラリアの感染性の変化を観察した. 羽化直後から 2 日間, 成虫用エサ（5\%フルクトース）に $10 \mathrm{mM} \operatorname{Trp}$ を添加した群と添加しない群とに分け, 虫体, 唾液腺, 中腸に おける XA 含有量を測定した. Trp を添加した群の虫体ではXA は 2 倍に増加したが, 唾液腺では逆に $1 / 2$ に減少, 中腸上に形成されたオオシス卜数も約半分になっていた. これは過剩 Trpにより, 蚊体内におけるXAの分布に変化 が起きたためと考察された。 